\title{
EFFECTIVE TEACHING AND LANGUAGE LEARNING MOTIVATION: A STUDY ON THE INTERCONNECTION
}

\author{
Zeinab Kafi \\ PhD Candidate, English Department, Islamic Azad University, Torbat Heydarieh Branch, Iran. \\ Email: kafizb@gmail.com \\ Khalil Motallebzadeh \\ Associate Professor, English Department, Islamic Azad University, Torbat Heydarieh Branch, Iran. \\ Email: kmotallebz@gmail.com
}

APA Citation: Kafi, Z. \& Motallebzadeh, K. (2015). Effective teaching and language learning motivation: a study on the interconnection. Indonesian EFL Journal, 1(2), 135-143

Received: 18-12-2014

Accepted: 21-04-2015

Published: 01-07-2015

Abstract: The present study aimed at examining the relationship between EFL teachers' effective teaching and the language learning motivation of Iranian EFL learners whose English proficiency was upper-intermediate and above. To this end, 150 upper-intermediate and advance EFL students, from some language schools in Mashhad, Iran participated in the study. The participants were firstly asked to fill out a researcher made questionnaire which aimed at checking their opinions on how effective they considered their teachers in teaching (Effective Teaching Questionnaire). Afterwards, the same students were asked to fill out a questionnaire that investigated how much motivated they were for learning English (Language Learning Motivation Questionnaire). These questionnaires were validated by two experts in the field, also their reliability, using Cronbach's Alpha, was estimated to be .87 and .80 respectively. Afterwards the relation between teachers' effectiveness in teaching and the extent to which students were motivated as a result was investigated. For measuring the probable relation, correlation as well as multiple regressions was run for analysis of the obtained data. The results exhibited the existence of a positive relation between the two.

Keywords: Effective teaching, motivation, EFL learners, EFL teachers

\section{INTRODUCTION}

Background and purpose

The question of what makes someone a good teacher is relevant for all teaching contexts, but it is especially important in the field of English as a foreign or second language where teachers can be hired simply for being a native speaker with a bachelor's degree (Darn, 2004, as cited in Cambridge English Teacher, 2014).

Generally speaking, there seems to be a widespread attention and research done regarding effective teaching which one is a sub category of quality teaching. Within a wider scope, nearly all teachers across the globe seem to be highly interested in knowing what could work best in their classroom and how it is possible for them to boost their teaching outcome in order to further satisfy the learners. According to Clark (1993) \& Sullivan (2001), "an effective teacher is one who demonstrates knowledge of the curriculum, provides instruction in a variety of approaches to varied students, and measurably increases students' achievement".

To the knowledge of the researcher the kind of interaction between and among teachers and students and how it is maintained has long been the focus of attention to many ELT researchers mainly because it is this kind of relation which gives us a thorough perspective on how effective teaching has taken place! Therefore, whether or not this effective teaching literally takes place in language classrooms or not needs to be studied thoroughly in order to inform any further changes the teachers may deem useful and needed.

Moreover, according to Papanastasiou (1999), who points out that "no single teacher attribute or characteristic is adequate to define an effective teacher", it is almost impossible to call a teacher an effective one 
simply based on the results of the students' grades, therefore a closer extraction of the elements contributing to effective teaching, at language schools as the immediate context of this study, was another point of discussion in this area of study.

To address the above mentioned problem, the researchers tried to answer the following questions:

Q1. Is there any significant relationship between effective teaching and Iranian EFL learners' language learning motivation? Q2. Is there any significant relationship between any of the four sub-categories of effective teaching and EFL learners' language learning motivation?

An important point motivating a work in this area is the status of teaching in general and its being effective in particular in Iran which has recently turned into a hot issue among ELT practitioners as well as teachers and its direct effect on students as a vast community. In other words, so many budgets on workshops, conferences, speeches and teacher awareness programs are spent so to improve the current teaching/learning status and outcome. Therefore, getting to know about how far teachers have been able to achieve this effectiveness and how significant its impact on students are, could be an issue of a high vitality, because it would certainly aid teachers in finding out if they have been moving within the perspectives or the purposes of teaching are not primarily met.

Finally, according to NAACE (National Association of Advisors for Computers in Education), we know that as technology develops and new learning and teaching opportunities arise as a result, new examples of good practice will emerge. E-Learning will offer new ways of learning, teachers will play new roles in the process and new models of excellent classroom practice will become apparent! Therefore, a more detailed analysis of these factors and its effectiveness in teaching as the result is deemed delightful to focus on!

Like any other researches, some inevitable (De) limitations, which may raise new questions for further researches in the same field in the future, will be imposed on. First of all, variables such as gender and personal variables are not taken into account. However, the most important restriction in this study is the fact that the notion of effective teaching is a vast area to focus on and as the context of this study was a language school whose students were mainly high school ones, and thus understanding all the categories and sub-categories of effective teaching was rather a tough task for them, the researchers mainly focused on those aspects of effective teaching which seemed more relevant to the realm of language teaching in language schools. Consequently, we would doubt about the extent to which the presence of other issues of effective teaching might influence the evaluation of these teachers in other similar academic/nonacademic contexts!

\section{Definition of key terms Motivation} Dornyei (1998) defines motivation as a "process whereby certain amount of instigation force arises, initiates action, and persists as long as no other force comes into play to weaken it and thereby terminate action or until the planned outcome has been reached".

\section{Effective teaching}

Effectiveness has been defined differently in different contexts and based on different purposes. The following definition is the operational definition for the present paper:

According to James and Sammons (2013), it is the ability to produce gains on student achievement scores; taking account of a baseline measure of students' prior attainment and other characteristics of student intake, the teacher effect is identified in relation to students' progress measured by later attainment. Such measures are often calculated in terms of progress over a school year.

\section{Literature review}

Possible ways for effective teaching to be maintained

According to Sharyn O'Neill, the director general of the government of Western Australia, teachers can to an almost 
absolute point, turn to be effective ones in the realm of teaching just in case they keep some factors highlighted in their profession. They namely include:

- $\quad$ Having High Expectations: She strongly believes that teachers should strive to motivate and engage all their students in learning rather than simply accepting that some students cannot be engaged and are destined to do poorly. Moreover, they should have high expectations of themselves and their own learning!

Acknowledging Individual

Differences: What is highly important here is the fact that teachers should bear this in mind that personalizing the learning for their students as well as knowing that students develop at different rates can help them up to a great deal. On top of all these, a teacher is to accommodate the different needs of students in his/her class rather than pitch his/her teaching to the middle.

- $\quad$ Using a Range of Pedagogies: this mainly centers on the fact that teachers should use techniques that best serve the learning needs of their students so that they can learn on themselves through discovery. Besides, effective teachers know that students learn best if they are provided with opportunities to learn not only from the teacher but also from other students and from sources outside the school that are now more readily accessible through various forms of technology.

Encouraging Student Responsibility: teachers had better teach in a way that encourages students to take greater responsibility for their own learning so to make sure their students know what the goals of the learning program are and therefore it results in Students being actively involved in evaluating their own learning.

Having Mastery over Their Teaching Content: this mainly highlights the fact that teachers are to have thorough knowledge of their subject content and skills and accordingly use their knowledge of learning processes to determine which will be most effective to help the particular students in their classes learn successfully.

- Monitoring progress and providing feedback: for teachers to be effective ones, it is absolutely necessary to closely monitor each student's achievements mainly because this gives them valuable information to assess the impact of their teaching. Effective teachers are also in the habit of constantly reflecting on how well they are getting through to their students and searching for better ways of teaching those who are not responding as well as extending those who are achieving well.

$$
\text { - } \quad \text { Providing a safe environment: }
$$

Provide a safe and orderly environment, both physically and emotionally so that students can achieve their potential because they Learn best if they are in a classroom where they feel safe and confidently attempt new tasks even if at first they are unsure about how to tackle them.

- Building Positive Relationships: teachers are advised to develop productive relationships with their students i.e. they get to know them and take a particular interest in their overall development and progress and also try to work collaboratively to benefit student learning.

\section{Effective teachers}

According to Kyriacou (1997), "over the years, thinking about effective teaching has been approached in a number of different ways. Until the 1960s, research on effective teaching was largely dominated by attempts to identify attributes of teachers, such as personality traits, sex, age, knowledge and training, which might have a bearing on their effectiveness. As long ago as 1931, for example, Cattell asked 254 people, including directors of education, teacher trainers, schoolteachers and pupils, to write down the most important qualities of the good teacher". However, as cited in Cambridge English Teacher (2014), there exist numerous definitions and characteristics of highly effective teachers and educators in this area have come up with variety of terms and notions, but they put forward a 10 characteristic list which they believe feel constitutes characteristics of excellence in our profession. They namely include:

- A "Calling" to the Profession( attitude, pride) 
- Professional Knowledge(Curriculum, context, programs, Technology)

- Personality/Personal Qualities(Creativity, patience, humor)

- With-it-ness (time, change)

- Instructional Effectiveness (deliver effective lessons)

- Good Communication Skills (how well a teacher conveys concepts \& skills)

- $\quad$ Street Smarts (politically-savvy)

- Willingness to Go the Extra Mile (make a difference in students' lives, high expectations)

- Commitment to Lifelong Learning (self/professional development, reflection, engagement)

- Life outside the Classroom (not being too consumed by the job! Teachers should find something that defines them out of the classroom).

After all, although all these tips might definitely help us develop teaching as our profession, it is also suggested to bear in mind the fact that there is really no single recipe to being a perfect teacher, nor is being perfect even realistic meanwhile teacher effectiveness, is the single biggest contributor to students' success mainly because it outweighs all the other factors such as class size, socio economic status and gender (Wenglinsky, 2000)!

\section{Motivation as a salient feature of language learning}

In educational psychology, the definition of what it is to be motivated is quite simple: "to be motivated is to be moved to do something." (cited in Xue, M., and Han, B., 2014).To the knowledge of the researcher there has never been an agreed upon concept for what motivation can be defined. However, it can be claimed that motivation is responsible firstly for why people decide to learn a language (herein this means English as a foreign language), how hard they are going to pursue this study and finally how long they are willing to sustain the activity (as cited in Kheradmandan, P. 2010).

Gardner (1985) identifies two types of motivation: integrative motivation and instrumental motivation. They define integrative motivation as the desire to achieve proficiency in a new language in order to know about the other culture and participate in the life of the community. Or in Cook's words, this type of motivation reflects the L2 learners' identification or rejection towards the target culture and its people (as cited in Kheradmandan, P. 2010).

Deci and Ryan (1985) also classify motivation into two types: extrinsic and intrinsic motivation. Extrinsic motivation comes from the desire to get a reward or avoid punishment; the focus is on something that is external or functionally unrelated to the activity in which they engage. To some extent, it has something in common with instrumental motivation. With intrinsic motivation the learning experience is its own reward. As Deci and Ryan (1985:245) put it, "Intrinsic motivation is in evidence whenever students' natural curiosity and interest energize their learning". In other words, intrinsic motivation exists when someone works because of an inner desire to accomplish a task successfully, whether it has some external value or not (as cited in Kheradmandan, P. 2010).

Moreover, based on what Xue (2014) states in his paper, Dornyei (2005) puts forward the famous three-level motivational theory namely as language level, learner level, and learning situational level, which consists of course-specific, teacher-specific and group-specific motivational components. Dornyei's framework is very concrete and highlights that motivation will be affected by situational factors.

\section{Related studies}

There have been similar studies carried out with regard to both or one of the variables. Since the 1990s, many researchers have done some studies on the interrelationship between language learning motivation and the use of language learning strategies (MacIntyre and Noels, 1996; Schmidt, Boraie, and Kassabgy, 1996; Schmidt and Watanabe, 2001). The results indicate that motivation is significantly correlated with strategies. However, few, if any, studies have been conducted to investigate the relationships of the two 
among Chinese college students who learn English as a foreign language. In order to bridge this gap, an exploratory study is carried out to investigate the relationships between language learning motivation and language learning strategies (as cited in Chun-huan, 2010).

Besides, it is worth noting here that a large number of researches have been carried out in china with regard to motivation. For instance, in China, motivation research began in the 1990s. Professor Wen Qiufang (2001) classifies learner's modified variables, among which motivation is closely related to belief and strategy on which deep motivation has more influence compared with surface motivation. Other research in China also finds motivation determines the success and failure of second language learning and has direct influence on strategy frequency. With regard to the other variable, effective teaching, studies related to this notion seem to be very rare in EFL context and those which are done are mostly qualitative ones aiming to define the construct or simply thinking of possible instruments to measure it as well as seeking different parties point of view about who an effect teacher can be. For instance, a number of studies have explored pupils' views of teachers and teaching (Cullingford, 2003; Haydn, 2007; Pollard et al., 2000).

Making a comparison between teachers' effectiveness in teaching and students' language learning motivation, is a hot issue embracing recent interest especially with regard to the notion of effective teaching in EFL context. Therefore, the researcher would investigate the probable relationship between the two variables.

\section{METHOD}

\section{Participants}

The participants in this study consisted of 150 EFL male and female students from 4 language schools in Mashhad Iran (Zabansara, Mahan, Shokuh and Elm - Fan Baran). Almost all of these participants marked their proficiency in English as Excellent and very good. The aforementioned participants were asked to fill in two researcher made questionnaires checking their ideas about how effective they considered their teachers' teaching and secondly how motivated they were for learning English as the immediate result of that teaching. The time allotted to each of these questionnaires was 15 minutes.

\section{Instrumentation}

The means of gathering data in this research were two researchers made questionnaires each of which will be discussed briefly:

\section{Effective teaching questionnaire}

In order to check students' opinion on how effective their teachers' teaching style has been, the researchers designed a 54 item questionnaire which asked students to mark their opinions on each of the 5 point likert scale items ranging from always to never. The questionnaire consisted of 4 categories on effective teaching (Engagement, Delivery of Instruction, Behavior Management and Selfawareness of Personal Features) each of which embraced up to 16 items. In order to design the questionnaire, the researchers went through a thorough corpus study and extracted the features of effective teaching from related textbooks and articles. Once the questionnaire was designed, two experts in the field commented and reviewed the items for the sake of the validation of the questionnaire several times and necessary changes were applied accordingly. Afterwards, its reliability was estimated after piloting the questionnaire, using Cronbach Alpha which revealed a high degree of .87 of reliability. The amount of time allotted for answering the questionnaire was 15 minutes.

\section{Language learning motivation questionnaire} In order to come up with how motivated students were for learning English, as a result of the effective teaching they had received, Liu's questionnaire on EFL Undergraduates' Motivation and their Autonomy in English learning (2008) was modified based on the purpose of the present study (extracting items related to motivation in language learning) and finally its reliability was calculated again $(.80)$. The questionnaire consisted of 23 five point likert scale ranging 
from strongly agree to strongly disagree. The amount of time allotted for answering the questionnaire was 15 minutes.

Procedure

In this study, the researchers investigated the probable relationship between EFL teachers' effective teaching and the extent to which their students were motivated in learning the language (English in this context). To this end, the date and time were arranged with the institutes in order to be able to administer the questionnaires to upper intermediate and advance EFL learners.

The process of collecting the data in the current study started in May 2015 and ended in July 2015 in several Language Schools (Zabansara, Mahan, Shokuh and Elm-Fan Baran). The data collection means in this study were two researchers made questionnaires. The questionnaires were administered in upper-intermediate and advance classes. The researcher was present all throughout the administration in order to ease the process for the participants and keep the conditions consistent.

As the researchers aimed at investigating the relation between effective teaching and language learning motivation, once the data was gathered, the results were analyzed through applying Pearson Correlation and Multiple Regression. And finally, the results were discussed in the teaching and learning setting.

\section{RESULTS AND DISCUSSION}

In order to find the answer to the first research question i.e. whether there exists a significant relation between effective teaching and EFL learners' language learning motivation, the correlation between effective teaching and learners' language learning motivation was estimated through Pearson Correlation. The data is presented in Table 1.

Table 1. Correlations: Effective teaching and language learning motivation

\begin{tabular}{|c|c|c|c|}
\hline & & $\begin{array}{c}\text { Language Learning } \\
\text { Motivation }\end{array}$ & Effective Teaching \\
\hline \multirow{3}{*}{$\begin{array}{c}\text { Language Learning } \\
\text { Motivation }\end{array}$} & Pearson Correlation & 1 & .095 \\
\hline & Sig. (2-tailed) & & .247 \\
\hline & $\mathrm{N}$ & 150 & 150 \\
\hline \multirow[t]{3}{*}{ Effective Teaching } & Pearson Correlation & .095 & 1 \\
\hline & Sig. (2-tailed) & .247 & \\
\hline & $\mathrm{N}$ & 150 & 150 \\
\hline
\end{tabular}

As depicted in Table 1, Pearson Correlation is .09 which is close to but smaller than 1; therefore, there exists an almost perfect positive correlation between effective teaching and EFL learners' language learning motivation. However, this positive relation between the two is not a significant one, probably because the participants weren't cooperative enough while answering the items in either of the questionnaires or due to their affective/ physical status at that moment.

In order to check which of the four subcategories of effective teaching (Engagement, Delivery of Instruction, Behavior Management and Self-awareness of Personal Features) possessed the highest level of correlation with the dependent variable (Language Learning Motivation), Multiple Regression was employed the result of which is revealed in Table 2 .

Table 2. Correlations: Engagement, delivery of instruction, behavior management, self-awareness of personal features

\begin{tabular}{llrrrrr}
\hline & & Motivation & Engagement & Delivery & \multicolumn{1}{c}{ Behavior } & \multicolumn{1}{c}{ Self-awareness } \\
\hline \multirow{3}{*}{$\begin{array}{l}\text { Pearson } \\
\text { Correlation }\end{array}$} & motivation & 1.000 & .080 & .172 & .072 & .000 \\
\cline { 2 - 7 } & Engagement & .080 & 1.000 & .449 & .361 & .421 \\
\cline { 2 - 7 } & Delivery & .172 & .449 & 1.000 & .370 & .603 \\
\cline { 2 - 7 } & Behavior & .072 & .361 & .370 & 1.000 & .369 \\
\cline { 2 - 7 } & Self-awareness & .000 & .421 & .603 & .369 & 1.000 \\
\hline
\end{tabular}




\begin{tabular}{lllrrrr}
\hline \multirow{2}{*}{$\begin{array}{l}\text { Sig. (1- } \\
\text { tailed) }\end{array}$} & motivation &. & .166 & .017 & .192 & .498 \\
\cline { 2 - 6 } & Engagement & .166 & .000 & .000 \\
\cline { 2 - 7 } & Delivery & .017 & .000 &. & .000 & .000 \\
\cline { 2 - 7 } & Behavior & .192 & .000 & .000 & .000 \\
\cline { 2 - 7 } & Self-awareness & .498 & .000 & .000 & .000 & .000 \\
\hline $\mathrm{N}$ & motivation & 150 & 150 & 150 & 150 & 150 \\
\cline { 2 - 7 } & Engagement & 150 & 150 & 150 & 150 & 150 \\
\cline { 2 - 6 } & Delivery & 150 & 150 & 150 & 150 & 150 \\
\cline { 2 - 6 } & Behavior & 150 & 150 & 150 & 150 & 150 \\
\cline { 2 - 6 } & Self-awareness & 150 & 150 & 150 & 150 & 150 \\
\hline
\end{tabular}

As for the analysis depicted in Table 2, Pearson Correlation, all the four subcategories of effective teaching possess a value of above .3 which proves the positive interrelationship which exists between the dependent and independent variables (.42, $.60, .36$ and 1 respectively). After all, to check which one of these relations is a statistically significant, the sig. goes to the "Delivery of Instruction" depicting a level of significance of .01 which is smaller than .05 !

In order to check the multicollinearity assumption and also for comparing the contribution of each of independent variables to the dependent variable, Coefficient Correlation is employed and the results are shown in Table 3.

Table 3. Coefficients of correlation

\begin{tabular}{|c|c|c|c|c|c|c|c|c|c|c|c|c|c|}
\hline & \multirow{2}{*}{ Model } & \multicolumn{2}{|c|}{$\begin{array}{c}\text { Unstandardized } \\
\text { Coefficients }\end{array}$} & \multirow{2}{*}{$\begin{array}{c}\begin{array}{c}\text { Standardized } \\
\text { Coefficients }\end{array} \\
\text { Beta }\end{array}$} & \multirow{2}{*}{$\mathrm{t}$} & \multirow{2}{*}{ Sig. } & \multicolumn{2}{|c|}{$\begin{array}{l}\text { 95\% Confidence } \\
\text { Interval for B }\end{array}$} & \multicolumn{3}{|c|}{ Correlations } & \multicolumn{2}{|c|}{$\begin{array}{l}\text { Collinearity } \\
\text { Statistics }\end{array}$} \\
\hline & & B & $\begin{array}{l}\text { Std. } \\
\text { Error }\end{array}$ & & & & $\begin{array}{l}\text { Lower } \\
\text { Bound }\end{array}$ & $\begin{array}{l}\text { Upper } \\
\text { Bound }\end{array}$ & $\begin{array}{l}\text { Zero- } \\
\text { order }\end{array}$ & Partial & Part & Tolerance & VIF \\
\hline \multirow[t]{5}{*}{1} & (Constant) & 76.017 & 9.521 & & 7.984 & .000 & 57.199 & 94.834 & & & & & \\
\hline & Engagement & .047 & .157 & .028 & .298 & .766 & -.263 & .356 & .080 & .025 & .024 & .732 & 1.366 \\
\hline & Delivery & .406 & .170 & .254 & 2.387 & .018 & .070 & .741 & .172 & .194 & .193 & .578 & 1.731 \\
\hline & Behavior & .060 & .167 & .032 & .357 & .722 & -.271 & .390 & .072 & .030 & .029 & .796 & 1.257 \\
\hline & $\begin{array}{l}\text { Self- } \\
\text { awareness }\end{array}$ & -.244 & .145 & -.177 & -1.682 & .095 & -.530 & .043 & .000 & -.138 & -.136 & .593 & 1.686 \\
\hline
\end{tabular}

According to Table 3, the Tolerance values for each of the four subcategories is smaller than $.10(.73, .57, .79, .59$ respectively), therefore it indicates that the multiple correlation with other variables is high, suggesting the possibility of multicollinearity. Thus, the multicollinearity assumption is not violated.

Standardized Coefficients (Beta) was used to compare the contribution of each independent variable to the prediction of the dependent variable. The larger the Beta value, the more contribution that particular independent variable depicts for the prediction of the dependent variable. The largest Beta value in Table 3 goes to "Delivery of Instruction", "Self-awareness", and "Behavior" respectively and the least amount of contribution is attributed to Engagement.

Finally, the sig. values are employed in order to check whether the Beta values are making a statistically significant contribution to the dependent value or not. Among all the four independent variables, "Delivery of instruction" depicts a statistically significant unique contribution to the prediction of the dependent variable $(.01<.05)$.

\section{CONCLUSION}

As illustrated through the data analysis and results, there existed a positive relation between EFL teachers' effective teaching and EFL learners' language learning motivation. Also, the four sub-categories of effective teaching revealed to have a high multiple correlation, and each of which contributed up to a point to the prediction of the dependent variable i.e. language learning motivation, above all stood the "Delivery of Instruction" which proved to have the strongest significant unique contribution to language learning motivation.

There has also been enormous attention and importance given to the notion of effective teaching by other language specialists and researchers in recent years. 
For instance some have attempted to systematically categorize different teaching behaviors and analyze the links between these categories and student achievement and as a result much has been written about specific effective teaching skills (Clark \& Peterson ,1986; Kyriacou ,2007; Muijs \& Reynolds, 2005; Philpott ,2009; Wragg ,1984), different teaching styles (Bennett ,1976; Galton, Simon \& Croll, 1980; Opdenakke \& Van Damme ,2006), and different models of teaching, which specify particular types of learning environment and approaches to teaching (Joyce, Calhoun \& Hopkins ,2008). These studies have shown that variations in teaching behaviours contribute much to teachers' effectiveness in the classroom. In addition, they reveal a high degree of consensus concerning the generic features of effective teaching (as cited in James and Sammons, 2013).

After all, what we teachers should constantly maintain and take care of, is the notion of effective teaching which can bring about and open the doors for our students' innovative, independent and motivated language learning styles and experiences. It would be definitely in this case that we have considered our teaching as a profession but not as a job/career! According to DarlingHammond (2000), the importance of maintaining and ensuring high quality teaching can be explained in this way:

"The effect of poor quality teaching on student outcomes is debilitating and cumulative. ...The effects of quality teaching on educational outcomes are greater than those that arise from students' backgrounds. ... A reliance on curriculum standards and state-wide assessment strategies without paying due attention to teacher quality appears to be insufficient to gain the improvements in student outcomes sought. ... The quality of teacher education and teaching appear to be more strongly related to student achievement than class sizes, overall spending levels or teacher salaries." (p. 3).

On the other hand, making sure that all students are enjoying and experiencing high quality teaching/effective teaching in one single classroom is a matter of skepticism and debate. However, although not sufficient enough, attracting high quality entrants to the teaching profession, and providing high quality pre-service education and ongoing professional development are important requirements for maintaining and raising standards in teaching (James and Sammons, 2013).

In conclusion, it can surely be claimed that effective teaching has got a main role in defining learners' language learning motivation and the only unstable factor could be the extent to which motivation or other language learning features might increase as the result of effective/ high quality teaching and this may mainly be attributed to high quality schools, learning environment, teaching/ learning aids and facilities and of course to more and less effective teachers! Accordingly, the need for a research on whether effective teaching is a stable factor or a flexible one, moving from the context of universities, to high schools or language schools is an immediate one!

Above all, the outcomes of the already carried out researches in this area can provide impetus to policymakers and practitioners to address the crucial issues of educational effectiveness, quality teaching and teaching standards.

\section{REFERENCES}

Bennett, N. (1976). Teaching styles and pupil progress. London: Open Books.

Chun-Huan, F. (2010). A Correlational Study of Language Learning Motivation and Strategies of Chinese Undergraduate. Canadian Social Science, 6(4), 202-209.

Clark, C. \& Peterson, P. (1986). 'Teachers' thought processes'. In M. Wittrock (ed.), Handbook of research on teaching, pp. 255-296. New York: Macmillan.

Coombe, Ch. (2014). 10 Characteristics for Highly Effective EF/SL Teachers. Cambridge English Teacher, Cambridge University Press and Cambridge English Language Assessment 2014.

Darling-Hammond, L. (2000). 'Teacher quality and student achievement: a review of state policy evidence'. Education policy analysis archives, $8(1)$.

Darn, S. (2004). Beyond Training and Teaching: A Review of the State of EFL in UK and out from UK. Humanizing Language Teaching. Retrieved June 24, 2013, from http;//www.hltmag.co.uk/may05/mart01.html, 
Deci, E. L., \& Ryan, R. M. (1985). Intrinsic motivation and self-determination in Human behavior. Plenum, New York.

Dornyei, Z. (1998). Motivation in second and foreign language learning. Language Teaching, 31, 11735. doi: 10.1017/S026144480001315X, http://dx.doi.org/10.1017/S026144480001315 $\underline{X}$

Galton, M., Simon, B. \& Croll, P. (1980) Inside the primary classroom. London: Routledge and Kegan Paul.

Gardner, R. C. (1985). Social Psychology and Second Language Learning: The Role

of Attitudes and Motivation, Edward Arnold, London.

James, K., and Sammons, P. (2013). Effective teaching: A review of research and evidence. Oxford University Press

Joyce, B., Calhoun, E. \& Hopkins, D. (2008). Models of learning, tools for teaching (3rd edn.). Buckingham: Open University Press.

Kheradmandan, P. How Can We Maintain Learners' LS Motivation in a Classroom Setting? A thesis submitted to the Department of Applied English Nanya Institute of Technology.

Kyriacou, C. (2007). Effective teaching in schools theory and practice. Cheltenham: Nelson Thornes.

Language Learning. In Z. Dörnyei and R. Schmidt (eds.) Motivation and Second Language Learning Acquisition. Honolulu: University of Hawaii Press.

MacIntyre, P, \& K. Noels. (1996). Using Socialpsychological Variables to Predict the Use of Language Learning Strategies. Foreign Language Annals, 29: 373-386.
Muijs, D. \& Reynolds, D. (2005). Effective teaching: evidence and practice (2nd edn.). London: Sage.

O'Neill, Sh. (2013). Effective Teaching. Australia: The Government of Western Australia.

Opdenakke, M. C. \& Van, J. D. (2006). 'Teacher characteristics and teaching styles as effectiveness enhancing factors of classroom practice'. Teaching and teacher education, 22(1), $1-21$.

Philpott, J. (2009). Captivating your class: effective teaching skills. London: Continuum.

Richards, J. C. (2001). Curriculum development in language teaching. Cambridge Language Education, Cambridge.

Schmidt, R., Boraie, D. and Kassabgy, O. (1996). Foreign Language Motivation: Internal Structure and External Connections. In Oxford R (ed.) Language Learning Motivation: Pathways to the New Century. Honolulu: University of Hawaii Press.

Schmidt, R. and Y. Watanabe. (2001). Motivation, strategy use, and pedagogical preferences in foreign.

Wen, Q. (2001). Developmental patterns in motivation, beliefs and strategies of English learners in China. Foreign Language Teaching and Research, 33, 105-110.

Wragg, E. (1984). Classroom Teaching Skills. London: Croom Helm.

Xue, F. \& Han, B. (2014). From Conflicts to Integration: An Empirical Study on Chinese EFL Learners' Construction of Bilingual Identities. Journal of Language Teaching and Research, 5(5), 11601166. 